\title{
"The Turkish Alcoran": New Light on the 1649 English Translation of the Koran
}

\author{
Mordechai Feingold
}

\begin{abstract}
The first translation of the Koran into English appeared in 1649, the first year of the Commonwealth. The political and religious significance of the publication was then and remains contested. In this essay, Mordechai Feingold traces the history of the translation's appearance, describing the personages and motivations involved with the publication and its reception. Arguing that Thomas Ross is the likeliest editor, he challenges an alternative identification of those responsible for the translation and paratexts. Feingold surveys the critical reception of the edition, which appears to have been partisan rather than principled, and concludes with a description of rival editions proposed by contemporary Arabists. KEYWORDS: seventeenth-century British views of Islam; licensing and censorship of religious works; religious politics of the Interregnum; John Boncle; Alexander Ross; English Arabist scholarship
\end{abstract}

ON MARCH 19, 1648/9, COLONEL ANTHONY WELDON cautioned the House of Commons about the imminent publication of a translation of the Koran into English. Ostensibly alarmed, the members ordered the serjeant-at-arms, together with an officer of the guards and several soldiers, to accompany Weldon, "make Search for the Press, where the Turkish Alcaron is informed to be now printing," seize the edition, and arrest the printer. ${ }^{1}$ This episode has often been cited, sometimes as a curiosity, sometimes to illustrate the vagaries of censorship, and sometimes as evidence of contemporary prejudices against Islam. Curiously, however, little attempt has been made

An earlier draft of this article was completed in March 2008. I wrote Noel Malcolm to ask whether he would be willing to offer comments, only to discover that he had just completed his own essay on the English translation of the Koran. A lengthy exchange of ideas ensued but, ultimately, we failed to agree on the identity of the translator. And as it proved impossible to publish our respective interpretations together, the following article should be read in conjunction with his essay: "The 1649 English Translation of the Koran: Its Origins and Significance," Journal of the Warburg and Courtauld Institutes 75 (2012): 261-95.

1. Journal of the House of Commons, 56 vols. (London, 1803-13), 6:168.

Pp. 475-501. (C)2013 by Henry E. Huntington Library and Art Gallery. ISSN 0018-7895 | E-ISSN 1544-399x. All rights reserved. For permission to photocopy or reproduce article content, consult the University of California Press Rights and Permissions website, http://www.ucpressjournals.com/reprintInfo.asp. DOI: 10.1525/hlq.2012.75.4.475.

HUNTINGTON LIBRARY QUARTERLY | VOL. 75, NO. 4 
to probe the circumstances surrounding the publication - and the presumed attempt at suppression-or to identify the individuals involved. Those who have analyzed the Alcoran of Mahomet have tended to take for granted that the prolific and long-winded Alexander Ross - who signed the "needfull Caveat" appended to the translation-was responsible for the entire production, even in the face of evidence to the contrary. This misattribution has led in turn to some untenable conclusions regarding the motives behind the publication - that the royalist Ross used the translation as a club with which to strike out at the loathsome "heretics" in Whitehall-and the environment within which Arabic studies in mid-seventeenth century England took shape. ${ }^{2}$ The purpose of the present essay is to shed new light on the publication of the "Turkish Alcoran" and the identity of its editor; to engage critically with a rival interpretation concerning the identity of the compiler; and to comment briefly on its relation to similar projects to edit (or translate) the Koran that were contemplated by contemporary Arabists.

The Alcoran of Mahomet was a translation of André Du Ryer's L'Alcoran de Mahomet translaté d'arabe en françois, published in Paris in early 1647 under a cloud. Writing to Claude Saumaise on May 31, Jacques Dupuy noted the recent ("depuis peu") publication of the book, further intimating that although the translation had been granted the appropriate privilege, the "Council of Conscience"-spearheaded by Vincent de Paul-sought to "smother its birth." Nevertheless, Dupuy observed, the Alcoran "is sold under the counter and this only serves to put up its price." 3 Copies of Du Ryer's translation seem to have been circulating by late March or early April: Henry Oxenden lent his copy of the "Turkish Alcoran" to "Mr Colbie of Patreksbourne" on April 4, 1647 (O.S.) for a period of six weeks. 4 The potential for commercial success that in part had motivated Du Ryer-a motive evident also in the unauthorized publication in 1649 of rival editions of Du Ryer's translation by Johannes Janssonius and Lodewijk III Elzevier in Amsterdam - was soon to be recognized in England as well. By June 1648 the millenarian Moses Wall informed Samuel Hartlib that a "friend" of his had completed the English translation. However, the friend had proceeded no further, as he waited for "a Historie of Mahomet's life and his Religion" promised to him. Six months later, on December 29, 1648, the completed manuscript was entered on the books of the Stationers Company. 5

The identity of the translator and/or editor, Thomas Ross, was revealed during the investigation that followed the printer's arrest. The surname has prompted speculation that Thomas was simply a misprint for Alexander. But in his "needfull Caveat," Alexander refers explicitly to the translator as being a person other than himself.

2. Nabil Matar, “Alexander Ross and the First English Translation of the Qur'an,” The Muslim World 88 (1998): 81-92, and Islam in Britain, 1558-1685 (Cambridge, 1998), 76-81.

3. Alastair Hamilton and Francis Richard, André Du Ryer and Oriental Studies in SeventeenthCentury France (Oxford, 2004), 55.

4. "Descriptive Catalogue of Documents Belonging to the Kent Archaeological Society," Archaeologia Cantiana 25 (1902): 256-98 at 257.

5. Sheffield University Library, Hartlib Papers (hereafter cited as HP), 31/22/9B; A Transcript of the Registers of the Worshipful Company of Stationers from 1640-1708, 3 vols. (London, 1913), 1:305. 
Equally to the point, Moses Wall noted that the translator had rendered into English other French works; Alexander Ross, by the date of publication a prosperous schoolmaster in London, had never engaged in any such translations. As for Thomas Ross, he was about to embark on a checkered political and literary career. From the mid-1650s on, his fortunes would become closely tied to Charles II, first in exile and then in England after the Restoration, whom he served as tutor and confidant to his illegitimate son, the Duke of Monmouth, and in various court positions. This later association with the king has influenced understandings of his political allegiance on the eve of the Koran's publication, as we shall see below. After being identified in connection with the Koran translation, he next appears in the records on February 17, 1653/4, when he was arrested, along with nine other men, "on suspicion of treason." Three months later, Thomas petitioned Cromwell and the Council of State to permit him to post bail, protesting he had "[n] ever acted prejudicially, nor harboured a mutinous thought." He had merely accepted an invitation by Richard Dutton to meet him in a tavern-with a group of people unknown to Thomas-whereupon he was arrested. The authorities granted Ross's request and released him on September 1, 1654, on "sufficient bail to the Lieutenant of the Tower to do nothing to the prejudice of the State."

Ross left for Cologne shortly thereafter, but by December he had returned to England, where he became involved in the uprisings planned for March 1655. Eluding capture, in early spring he made his way to Paris, where he proved himself an important royalist agent, while his wife, Alice, stayed behind in England, becoming a resourceful intelligencer and a courier. During his two-year sojourn in Paris, Ross endured considerable financial hardship. He confided to Edward Nicholas in early January 1656 that he was unable to settle debts to his physician or to pay for a pass to England: "all I can do [is] to pay for my letters, and I often spare it out of my belly." Although he had tutored Wentworth Dillon, fourth Earl of Roscommon, for the previous seven months, the boy's guardians could not "find money to send him here, so I am destitute of all support." In fact, Ross concluded in a subsequent letter, he had "never before been in so sad a condition." His wife found herself equally constrained: "for want of maintenance in London, [she had] been obliged to retire" to his mother's house in Richmond. Ross articulated his distress when petitioning Charles II in November 1656 for the position of yeoman of the Removing Wardrobe-in the event the king was restored to the throne: "I have ever been your loyal and faithful servant during the late horrible rebellion, and thus lost my fortune to the ruin of myself and family." 7

By 1657 Ross's fortunes had begun to turn. He acquired additional aristocratic students-including Edward Stanley, younger brother to Charles Stanley, eighth Earl of Derby-and rose quickly in the esteem of the king. In March 1658 Charles II entrusted him with the delicate task of abducting his natural son James Scott, the

6. Calendar of State Papers, Domestic [The Commonwealth; hereafter cited as CSPD], ed. Mary A. E. Green, 13 vols. (London, 1875-86), 1653-1654, 407; CSPD 1654, 165, 273, 353. Dutton, who was ordered banished, became governor of Barbados after the Restoration; see David Underdown, Royalist Conspiracy in England, 1649-1660 (New Haven, Conn., 1960), 131-33 and passim.

7. CSPD 1655-56, 80, 123, 237; CSPD 1656-57, 179. 
future Duke of Monmouth, from the boy's mother. "I wondered at the King's choosing me for this task," Ross confided to Nicholas on March 25/April 4, 1655, before guessing the king's intention: "I believe I am designed for his tutor." ${ }^{8}$ Ross would remain Monmouth's tutor and confidant almost until his own death in 1675 , exerting considerable influence over the young man-or so contemporaries whispered. Certainly, James II believed that those "ambitious thoughts which had taken possession of [Monmouth's] brain... were probably first instill'd into him" by Ross, who hoped "therby to make his own fortune." 9

The intimacy between Ross and Monmouth did little to diminish the king's regard for Ross. Following the Restoration, Ross was appointed keeper of the King's Library and groom to Charles's Privy Chamber, and allotted considerable monetary gifts. Ross made public his gratitude with a verse translation of Silius Italicus, The Second Punick War between Hannibal and the Romanes (1661). He prefaced the book with the original dedication, which he had prepared upon presenting the manuscript to Charles II in November 1657. He did not presume to present the monarch with "Examples for Imitation," Ross avowed, but desired that by reflecting on such examples the king "may see what unperishable Monuments Great Persons may build to themselves, in asserting their Country." And as the king "is endowed with all those Virtues, that rendred the Valiant HANNIBAL famous, or SCIPIO a Conquerour: so, by the blessing of Heaven on Your Majestie's Designs, some happy Pen may have Matter to build you such another Monument for future Times; and that Your Majesties' Kingdoms being Restored to their former Glory by Your Hand, Posterity may date their Happiness from Your Conquest; and Your Name become an eternal Terrour to Rebellion." ${ }^{10}$ Subsequent literary works - translations of Cicero and Claudian, as well as a letter of advice to the young duke-Ross dedicated to Monmouth. ${ }^{11}$

In 1648 , however, Ross was still a young man on the make. Although he certainly had family connections to the court-his father James Ross had been for many years page of the bedchamber in ordinary to Charles I-there is no evidence of his personal political commitments or connections until later. It was becoming clear, in fact, that he could not count on his inheritance for a living and would have to shift for himself. The second son of James by his second wife, Jane, Thomas had been baptized in Richmond, Surrey, on September 11, 1620. He was admitted exhibitioner of the Charterhouse School in London on July 12, 1631, and pensioner of Christ's College, Cambridge, on

8. CSPD 1657-58, 342.

9. J. S. Clarke, The Life of James the Second, 2 vols. (London, 1816), 1:490-91.

10. Thomas Ross, The Second Punick War Between Hannibal and the Romanes (London, 1661), sig. B2-B2v.

11. Curt A. Zimansky, “The Literary Career of Thomas Ross," Philological Quarterly 21 (1942): 443-44; J. P. Vander Motten and Katrien Daemen-de Gelder, "A 'Copy As Immortal, as its Original': Thomas Ross' Second Punick War (London, 1661 and 1672)," in Living in Posterity: Essays in Honour of Bart Westerweel, ed. Paul Hoftijzer et al. (Hilversum, Netherlands, 2004), 185-90; Christopher Bond, "The Phoenix and the Prince: The Poetry of Thomas Ross and Literary Culture in the Court of Charles II," Review of English Studies 6o (2009): 588-604; Katrien Daemen-de Gelder and Jean-Pierre Vander Motten, "Thomas Ross's Second Punick War (London 1661 and 1672): Royalist Panegyric and Artistic Collaboration in the Southern Netherlands," Quaerendo 38 (2008): 32-48. 
June 4,1639 . He graduated with a bachelor of arts in $1642 .{ }^{12}$ Thomas's whereabouts for the next six years are unknown. His older brother William, fellow of King's College, Cambridge, left for Oxford in 1643 to join the king's army-dying there in November of that year-and Thomas may have followed him to Oxford. It is more likely, however, that he embarked on a Continental tour, for his father's legal arrangements suggest Thomas was out of the country by January of 1643 . When James Ross drew up his will on May 20, 1642, he appointed his two sons as executors. On January 20, 1643, however, shortly before he died, James substituted as executor his cousin Robert Ross for Thomas-without changing the content of the will—-thereby indicating that he did not expect Thomas to be "about me at the time of my decease." James valued his ready money, obligations, and plate at $£ 1,600$. His wife received $£ 650$ and the property of the house for the duration of her widowhood, at which time both money and goods were to be divided between the two sons. William was bequeathed $£ 100$ and the possession of the lands of Grantham Manor, Lincolnshire, due to revert to him in 1646 for fortysix years. Thomas received $£ 200$ as well as the constableship of the Launceston Castle for life. According to the terms of the will, Thomas stood to inherit possession of Grantham Manor following his brother's death. But in 1643 Parliament confiscated the manor and bestowed it on two supporters. If Thomas got any income from the constableship, furthermore, it was not for long. By 1650 Parliament had sold Launceton Castle to the influential colonel Robert Bennett. Ross attempted to challenge the sale, but in July 1652 the committee rejected his petition. Ross hardly exaggerated, therefore, when he complained to Charles II in 1656 that in adhering to the royal cause he had "lost [his] fortune to the ruin of [himself] and family." 13

Whatever pursuits Thomas Ross followed during the 1640s, in late December 1648 he handed over the manuscript of The Alcoran of Mahomet to the bookseller John Stephenson, who also appears to have been a rising man. Stephenson, who began publishing in 1649 , kept a shop at the Sun on Ludgate Hill. He remained active for only three years, probably either abandoning the trade in 1652 or dying. His short list of publications was commensurate with his stature in the profession: a piece of juvenilia by Thomas Manley Jr., Temporis Angustiae: Stollen Houres Recreations (1649); a couple of educational treatises by James Shirley (Via ad Latinam linguam complanata [1649]) and George Snell (The Right Teaching of Useful Knowledg [1649]); Jeremiah Rich's Mellificium Musarum: The Marrow of the Muses (1650); Humfrey Brown's The Ox Muzzled... Or a vindication of the church's rights against all her sacrilegious enemies (1650); several pamphlets by Edward Williams relating to Virginia; and Edward Bland's The Discovery of New Brittaine (1651). In 1650 Stephenson also published Alexander Ross's epitome of Sir Walter Raleigh's History of the World (1650) - which obviously capitalized on the

12. John Peile, Biographical Register of Christ's College, 1505-1905, and of the Earlier Foundation, God's Houses, 1448-1505, 2 vols. (Cambridge, 1910-13), 1:461; F. N. R., "Ross Family," Scottish Antiquary 7 (1893):17-18.

13. The National Archives, Kew [hereafter cited as TNA], PROB 11/191/84, fols. 59-59v (quotation on fol. 59v); Folger Library, MS X.d.483 (164-167); Scottish Antiquary 8 (1894): 26-27; Western Antiquary 10 (1891): 66-67; CSPD 1656-57, 179 (quotation). 
relationship forged the previous year, and may even have been a payback of sorts to Alexander Ross.

The printer that Stephenson approached for the project was Robert White, who had kept shop at Warwick Court since 1639. In 1647 White co-produced, with Thomas Brudenell, a pocket edition of the Bible, and published William Sprigge's Anglia Rediviva. His main business at the time, however, was newsletters. White printed the official publication The Moderate Intelligencer, edited by John Dillingham. Gilbert Mabbot, the licenser of newsbooks, tried and failed to gain control over that weekly in 1648 , at which point White joined Mabbott in launching and printing a rival publication, The Moderate. It was White who entered on December 29, 1648, the manuscript of The Alcoran of Mahomet in the Stationers Company's books. ${ }^{14}$ There is nothing to suggest that Ross or Stephenson or White contemplated anything but profit. A translation of the Koran with a life of the prophet was certain to generate sales-a consideration, as noted above, that had informed Du Ryer's edition as well as the unauthorized Amsterdam editions. As for the risks, I shall argue below, these seemed rather negligible given the aim of the publication. What Ross and Stephenson failed to foresee, however, was the concerted effort by a disgruntled soldier to avail himself of the translation of the Koran for opportunistic purposes.

\section{筩}

The story of the challenge to the publication suggests that, for many involved, the Koran was seen as a handy political weapon rather than a genuine threat to Christian religion. Certainly the man who brought it to the attention of Parliament is known primarily for a series of attempts to gain publicity and attract sympathy from the government. Anthony Weldon was a professional soldier who had served on the Continent from an early age before returning to England in 1639 to fight on the side of Parliament. From a petition he submitted to Parliament in 1645 , he emerges as self-righteous, maybe even paranoid, convinced that every commander under whom hed ever served was incompetent and ungrateful. The petition catalogued his superiors' objectionable actions, which ranged from tolerating papists to ineptitude and cowardice, not to mention failure to appreciate his services and reward him accordingly. Weldon did not hesitate to make his complaints public, petitioning both his superiors and Parliament. But in 1644 he seems to have gone too far; after denouncing Sir Michael Livesay as "Mutineer and a coward," he found himself imprisoned in Newgate. Ten months later, still in prison and owed $£_{500}$ in arrears, Weldon published a narrative of his sufferings that included additional petitions to Parliament to either give him satisfaction or permit him to go overseas. He was granted the latter. ${ }^{15}$

14. Henry R. Plomer, A Dictionary of the Booksellers and Printers Who Were at Work in England, Scotland and Ireland from 1641 to 1667 (London, 1907), 193, and "A Printer's Bill in the Seventeenth Century," Library, 2nd ser., 7 (1906): 32-45. For the founding of The Moderate, see Joad Raymond, The Invention of the Newspaper: English Newsbooks, 1641-1649 (New York, 1996), 65-66.

15. The True Declaration of Colonell Anthony Welden, to the Honourable House of Commons of those services hee hath done them, the ill encouragements hee hath had by the unjust oppressions of some potent 
By 1648 Weldon was back in England attempting to gain another commission. He was ignored. Ultimately, Sir Thomas Fairfax took pity on him and, on February 6, 1648/9, wrote a letter to the Committee for the Army, requesting permission for Weldon to transport a regiment of 1,500 men beyond the seas. Unable to get the letter read, Weldon printed it for distribution among members of Parliament and other grandees, but to no avail. He could gain neither employment nor his arrears. Even the most tyrannical governments-Weldon lashed out in frustration in a new narrative of his sufferings-listened to petitions and remedied wrongs. But evidently not in England, where justice gave way to the rule of favoritism. ${ }^{16}$

Precisely at this point, Weldon discovered, "by chance," that the Turkish Alcoran was being printed, licensed by authority, and unprotested by any clergymen "whose duty it was properly" - he wrote-to object. Consequently, he felt "bound in conscience" - as clergymen ought to have been - to preserve the honor of Parliament and God's glory from the scorn certain to be heaped on them from "the permission of such blasphemy." Weldon therefore petitioned Parliament "to have it burnt; for [he] thought it very strange a Law should be against the speaker of blasphemies, and none against blasphemie printed by authority." His petition put a stop to the printing, Weldon narrated, but he then dropped the matter, having discovered that even "so innocent" an action brought great enmity on him. According to Weldon, "many would have had it out to have rendred the Parliament more odious in their actions; many thinking, if it were tolerated, they could not then deny any Christian doctrine for shame." Hugh Peter's reaction, in particular, baffled him. That influential Independent minister publicly chided Weldon in the lobby of the House of Commons: "I wonder thou keepest a quoil in the coming forth of the Alchoran, no new thing here; and in his reason it should be permitted." Rebuffed in Parliament, Weldon turned to the Council of State, only to be dismissed by Secretary Gualter Frost as "too troublesome." He had spent his own time and money, Weldon insisted, not for his own interests but "for Gods glory, and the good of the Common-wealth." Surely he deserved better. ${ }^{17}$

Whether Weldon hoped to ingratiate himself with Parliament by showing himself vigilant against blasphemy, or in frustration he intended to embarrass the House of Commons by exposing its acquiescence to the publication of a sacrilegious book remains unclear. Whatever his motives, Weldon found it necessary to apply for a pass to leave England, and such was granted to him, his wife, and three servants on April 20, $1649.1^{18}$

If Weldon's denunciation of the Alcoran of Mahomet was not motivated by excessive piety, neither was the subsequent course of action taken by Parliament. The

adversaries for their owne private ends, hath caus'd his infinite sufferings, all which humbly representeth to them, craving reliefe from them as fathers of their country to relieve the oppressed (London, 1645).

16. Anthony Weldon, To the Parliament of England and Army. The declaration of Colonel Anthony Weldon, of his faithfull services, and sufferings by oppression for them since the beginning of this war to this present, without any manner of redresse, and his necessitated resolutions thereupon (London, 1649), 34-37.

17. Ibid., 37-38.

18. CSPD 1649-1650, 530 . 
decision to stop printing was undoubtedly informed by political expediency. Six weeks after the execution of Charles I, the purged Parliament was extremely wary of the press and sensitive to the increasing attacks on Oliver Cromwell and on the regime more generally - attacks that often likened the arbitrariness of the government and army rule to Turkish tyranny. Understandably, then, in view of the complaint, and in the absence of any other information, the translation of the "Turkish Alcoran" at that precarious moment could not but be considered a subversive publication. ${ }^{19}$

With this context in mind, we may resume the narrative of events. On March 21, two days after Weldon petitioned Parliament, the speaker informed the House that Robert White, the printer, had been arrested and the copies confiscated. The members also discovered that the book had actually been licensed by John Downame, the official licenser of divinity books since 1643. They resolved to refer the entire affair to the Council of State, "further to examine the Matter; and to discharge the Prisoner, or continue him in Prison, as they should find Cause; and to take what further Order they shall think fit for the Suppressing of the Books, and further Imprinting of them." 20 White was the only one apprehended, an injustice that rankled his partner, Mabbott, who proceeded to vent his disapproval in The Moderate a few days later: "though the Printer had a license according to Ordinance of Parliament, for the Printing thereof: This is to punish the Innocent for the Nocent." Worse still, referring the matter to the Council of State "to proceed therein as they see cause," was offensive; the grounds for action should "be according to Justice." 21

On March 29, the Council of State attended to the case. Sir James Harrington, Alderman Rowland Wilson, and Luke Robinson were appointed to a committee "to examine the business of printing the Alcoran," and in this capacity they summoned Stephenson and Downame to appear that afternoon. Quite possibly nothing happened, for two days later it was resolved to summon both Stephenson and Thomas Ross. The release of White was also ordered, "on giving security to be forthcoming." Finally, on April 4, they dismissed Ross "with a monition not to meddle more with things of that nature."22

Only at this late stage did Alexander Ross become involved in the affair. Whether Thomas Ross (or Stephenson) appended a caveat by Alexander because they concluded it was prudent, or in response to a demand by the authorities, cannot be determined. Alexander Ross claimed that he had been moved to compose it "upon intreaty of some learned and religious Men." We may speculate with some confidence that the decision to enlist the ready pen of Alexander Ross derived, in part, from his being a relative of Thomas and, in part, from his reputation as the most stalwart defender of learned orthodoxy. Indeed, his conservatism and prolificity were such that, when in 1654 Richard Whitlock castigated the outpouring of the press, he used

19. For a brief discussion of the deployment of the despotic imagery, see Glenn Sanders, "A Plain Turkish Tyranny': Images of the Turk in Anti-Puritan Polemic," in Puritanism and Its Discontents,

ed. Laura L. Knoppers (Newark, Del., 2003), 167-93, esp. 179-82.

20. Journal of the House of Commons, 6:170.

21. The Moderate, March 20-27, 1649, sig. Oov.

22. CSPD 1649-50, 59, 63, 70 . 
Ross as an example not only of a man who wrote to make ends meet but also of an ignoramus who flails at his betters: "write they must against Things or Men (if the Spirit of contradiction prove saleable) that they can neither Master, nor Conquer; sparing neither Bacons, Harveys, Digbys, Brownes, or any the like of Improvement COLLEDGE ... though (beside some little somewhat for the venture) they get nothing, but such a credit as he did, that set Diana's Temple on fire, to perpetuate his Name." The derision was picked up five years later by Francis Osborn, who added his own objection to Ross, "who used to skirmish (though only armed with a blunt quill, and a duller Reason) the Worthies of our Nation by Troops." 23

It was precisely such conservatism that endeared Alexander Ross to the godly censor John Downame, who was in the habit of adding personal commendations to those books of Ross he had licensed. Downame found Medicus medicatus-Ross's blistering attack on Sir Thomas Browne's Religio Medici and Sir Kenelm Digby's reflections on that book- "learned, sound and solid," further recommending it so that "many others may receive the same satisfaction, content and delight in reading of them, which I professe my selfe to have enjoyed in their perusall." The same year, 1645, Downame licensed Ross's critique of Digby's Two Treatises in equally approving terms: "Having with much delight, satisfaction, and content perused this Treatise, entituled, The Philosophicall Touch-stone, I allow it to be printed and published, and commend it to the learned and judicious Reader, as a work sound and solid, and eminently acute and accurate." 24

Surely, then, a caveat by such a die-hard conservative-albeit a royalist-was expected to go a long way toward allaying any lingering concerns about subversiveness, and Ross certainly did not disappoint. Within merely a week or two after Thomas Ross was dismissed by Parliament, Alexander Ross produced "A needfull Caveat or Admonition for them who desire to know what use may be made of, or if there be danger in reading the Alcoran." He argued on various lines that pious Christians need not fear its influence. Rendering the Koran-a "gallimaufry of Errors, (a Brat as deformed as the Parent, and as full of Heresies, as his scald head was of scurffe)"-into English, Alexander Ross speculated, was intended by the translator to be akin to the public display of a monster: a spectacle that induces the observer to bless his good fortune for not being thoroughly deformed. Analogously, reading the Koran would spur one to "enjoy the glorious light of the Gospel, and behold the truth in the beauty of holiness." 25

Some may regard the publication, Ross continued, as "dangerous to the Reader, scandalous to the higher powers." The authorities, however, saved face, having "cleared

23. Richard Whitlock, Zootomia, or Observations on the Present Manners of the English (London, 1654), 232; Francis Osborn, A Miscellany of Sundry Essaies, Paradoxes, and Problematical Discourses, in The Works of Francis Osborn (London, 1673), "The Author to the Reader," sig. Pp7.

24. Alexander Ross, Medicus medicatus, or, The physicians religion cured by a lenitive or gentle potion with some animadversions upon Sir Kenelme Digbie's observations on Religio medici (London, 1645), sig. A8v, and The philosophicall touch-stone, or, Observations upon Sir Kenelm Digbie's Discourses of the nature of bodies and of the reasonable soule in which his erroneous paradoxes are refuted, the truth, and Aristotelian philosophy vindicated (London, 1645), license facing the title page.

25. The Alcoran of Mahomet, sig. Ee. I used the edition catalogued as Thomason, E.5533 and Wing (2nd ed.) K747; pagination varies slightly from the two other editions published in 1649. 
themselves by disliking the publishing, and questioning the publishers thereof." As for the readers, they may rest reassured by the "admonition" he had prepared: "staid and solid Christians" who read the Koran are at no greater risk than those perusing errors recorded in scripture, the errors of "ancient and modern Hereticks," or even the ancient poets. Nor is there anything of beauty in "such a mishapen and deformed piece" that might tend to win over any readers. Just the opposite. The hideousness of the content should confirm Christians in the truth of their convictions. The Koran may be spread widely, but only on account of its promoters' brute force and its proselytes' ignorance, not of its intrinsic value. Arguing further, he noted the necessity of knowing evil in order to avoid it; hence, familiarity with the Koran would enable the reader "to beat Mahomet with his own Weapons." Nevertheless, even in the "dirt of the Alcoran" one may "find some jewels of Christian vertues," for example, edifying instances of charity and piety. To conclude, then, in Ross's words, "they only may surely \& without danger read the Alcoran, who are intelligent, judicious, learned, and throughly grounded in piety, and principles of Christianity; but weak, ignorant, inconstant, and disaffected mindes to the truth, must not venture to meddle with this unhallowed piece, lest they be polluted with the touch thereof." 26

Thomas Ross penned his own brief introduction following his interrogation by the Council of State. It restated in less than six hundred words parts of the message conveyed by Alexander Ross in his prolix caveat, albeit in a distinctly defiant manner. The present proliferation of sects and heresy, Ross noted sarcastically, wanted only Islam, so he "thought good to bring it to their Colours, that so viewing thine enemies in their full body, thou mayst the better prepare to encounter, and I hope overcome them." Some may be startled to encounter an English translation of the Koran; but the book had already been translated to most European languages "yet never gained any Proselyte, where the Sword, its most forcible, and strongest argument hath not prevailed." Further to alleviate fears, Ross alleged an abundance of absurdities and contradictions that permeated the Koran, so much so that even "some modest, and more rationall Mahometans" felt it necessary to excuse the text. And still, the Koran is esteemed so sacred for Muslims that only "he who is clean" may touch it, while the vulgar are prohibited from reading it, forced to "live and die in an implicite faith of what their Priests deliver" - which, as Grotius observed, "is a manifest argument of its iniquity." Following a line of reasoning traversed by John Milton five years earlier, Ross pronounced: "that merchandise may justly be suspected which will not be sold, unlesse unseen." Consequently, Ross feigned not to understand the attempt to proscribe the book: "some, conscious of their own instability in Religion, and of theirs (too like Turks in this) whose prosperity and opinions they follow, were unwilling this should see the Press." Yet, Ross insisted, no reader, who "hast been so true a votary to orthodox Religion, as to keep [himself] untainted of their follies" could be hurt by the book. "And as for those of that Batch, having once abandoned the Sun of the Gospel, I believe they will wander as far into utter darkeness, by following strange lights, as by this Ignis Fatuus of the Alcoran." 27

26. Ibid, sigs. Eev, Ee4-Ee5v, $\mathrm{Ff}_{3}$.

27. "The Translator to the Christian Reader," ibid., sig. A3-A3v. 
The Alcoran of Mahomet was published in late April, without identifying either publisher or printer, and without any display of Downame's imprimatur. By May 2 John Dury informed a correspondent, "The Alcoran is come forth in English"; five days later the bookseller George Thomason acquired his copy. ${ }^{28}$ The expectation of a commercial success was fully realized. A second edition was called for before the year was out. Sir William Davenant may well have alluded to such a success when commenting in his Gondibert on "the Arabian's Gospel": "The Curious much perus'd this, then, new Book; / As if some secret ways to Heav'n it taught." ${ }^{29}$ Contrary to received opinion, however, no public controversy ensued.

\section{怒}

Before turning our attention to the reception of the book, I'd like to examine, and reject, an alternative identification of the English translator. I would argue that in the absence of any documentary evidence to connect an alternative candidate to the translation of the Koran, rejecting the existing evidence regarding the editor is unwarranted. This argument is of broader import because it assumes stable and uncomplicated divisions between citizens in the Commonwealth period, overstating the degree to which the intellectual community was split along partisan lines and the consistency of individuals' alignments. I argue rather that the boundaries between roundhead and royalist men of letters were fuzzy, and that alliances were frequently opportunistic. The reception of the Koran was itself highly opportunistic. Few seem seriously to have believed that it posed grave danger to religion. The publication of the Alcoran of Mahomet fit conveniently into a particular mode of antigovernment propaganda that equated Parliamentarians with tyrants, tyrants with Turks, and Turks with the Koran.

In a recent essay Noel Malcolm challenges the notion that Thomas Ross had been responsible for any part of the Alcoran, relegating him to the position of a courier-the person who, literally, "delivered" the manuscript to the printer. A strong reason for disqualifying Ross as the translator, Malcolm asserts, "is the simple fact that Hartlib described that translator as 'a Friend of Mr Wahl's." Malcolm posits that, because Moses Wall had been so passionately and so vehemently opposed to the royalist cause-his few identifiable associates were all radicals and proponents of Parliament-he would not have befriended a "royalist activist" like Thomas Ross. In view of Thomas Ross's subsequent activism in the royalist cause, Malcolm adds, and his future translations from the classics, "one might have expected him either to have been hard at work producing polemically royalist underground publications, or to have retreated to the world of ancient Rome; translating the Koran seems out of keeping with both of these scenarios." Finally, Malcolm objects, not only is there no evidence that Thomas Ross produced other translations from French - as Hartlib also credited the translator of the Alcoran for doing — but, given his "intellectual profile," he

28. HP 4/1/26B; Catalogue of the Pamphlets, Books, Newspapers, and Manuscripts relating to the Civil War, the Commonwealth, and Restoration, Collected by George Thomason, 1640-1661, 2 vols. (London, 1908), 1:742.

29. William Davenant, Gondibert, ed. David F. Gladish (Oxford, 1971), 157. 
could have easily written the life of Muhammad himself, without the need to wait for someone else to write such an account. ${ }^{30}$

Malcolm's line of reasoning seems to me problematic on multiple grounds. First and foremost, there exists no evidence for crediting Thomas Ross with royalist activism of any sort before 1654 . For all we know, he settled down after returning from Cambridge (or a Continental tour) to a retired learned life, perhaps in the family home at Richmond, the ownership of which he shared with his mother. He may have become radicalized in the king's cause only gradually in the aftermath of the execution of Charles I in January 1649-as was the case with many Englishmen. The arbitrary revocation in 1652 of the deed that granted him the constableship of Launceston Castle may have also contributed to his growing alienation. Certainly, when he was arrested in February 1654, the authorities did not indicate any prior involvement by him in royalist activism, hence his release on bail alone, whereas three of those arrested with him were banished from England, while the estate of the fourth was sequestered. In the late 1640 , therefore, Thomas Ross was hardly a firebrand, and there is no reason to assume that he and Wall could not move in similar circles. The era of Civil War and Interregnum offers numerous instances of scholarship bridging political and religious differences, and Ross and Wall-both Cambridge graduates who shared many learned interests-could easily fit the pattern. (Needless to add, one need not interpret Hartlib's "friend" to mean a bosom buddy.)

Second, to argue that a translation of the Koran in the late 1640 s would have been out of character for someone who is known to have subsequently published several translations from the Latin is perplexing. Thomas Ross was renowned for his wide and varied learning and, like many contemporaries, his range of interests almost certainly transcended the narrow confines of the classics. Besides, as I argued above, the Koran translation was probably intended to be a commercial venture, not a serious scholarly enterprise. Indeed, it is quite possible that Ross actually commissioned a far more substantive life of Muhammad than the one he ultimately published-and hence the several months' delay between his completion of the translation and the delivery of the manuscript to the printer. If so, it might even be possible to offer a conjecture concerning the identity of the prospective author: the young orientalist Thomas Smith, who had been an exact contemporary of Ross at Christ's College in the early 1640 .

Smith's correspondence with Hartlib reveals the sad struggle of an impoverished royalist in Puritan Christ's College, whose master and several fellows endeavored to make him "weary of the College" by any means possible. Thus, Smith intimated, they refused to assign him fee-paying students, unlawfully withheld his meager stipend as lecturer in rhetoric-endowed specifically for him by William Chappell, bishop of Cork and Ross-and forced him to assume punishing teaching duties in College. Such duties included "reading in the same weeke (or day) publique lectures, Hebrew Greeke Rhet. Logick, Phisicks, besides common place twice a weeke now \& then \& other exercises as moderating as Head Lect. at all disp. \& declamations in the

30. Noel Malcolm, “The 1649 English Translation of the Koran: Its Origins and Significance," Journal of the Warburg and Courtauld Institutes 75 (2012): 274-75. 
Hall." Small wonder, then, that the embittered scholar lamented his lot: "finding so little encouragement \& conceiving my selfe condemned for ever to grind in pistrino paedagogico I neglected those delightfull employments whereto my nature leades me \& found I had worke enough to get food \& raiment." 31

Smith, therefore, would have been an ideal candidate for writing the life of Muhammad, both on account of his knowledge of the subject matter and as means to generate some badly needed income. If Smith was the person Ross commissioned, it is easy to understand how the daily struggle at Cambridge could have prevented him from delivering the "Life." Ultimately, we may further conjecture, it fell to Ross himself to compose the biography. As Malcolm points out, the final product represents a clever pastiche of material derived mostly from Michel Baudier's Histoire générale de la religion des turcs and Samuel Purchas's Pilgrimage - a composition that could have certainly been carried out within a short amount of time. ${ }^{32}$ And if we credit Thomas Ross with the authorship of the "Life," then we may also credit him with the abortive English translation of Baudier. On April 23, 1649, the stationer Henry Seile entered in the Register of the Stationers' Company "a booke called The generall history of the religion of the Turkes." Like the Alcoran, this translation had been licensed by John Downame, and one may further speculate that, having utilized Baudier's book for the composition of the life of Muhammad, Thomas Ross decided to embark on a full translation of the work. 33 Or perhaps he had done so while waiting for the delivery of the "Life," which would nicely tally with Hartlib's noting that the translator of the Alcoran had "translated other works out of French."34

Malcolm's disqualification of Thomas Ross because it is unlikely that Moses Wall would have befriended a royalist is further complicated by the fact that Malcolm's preferred candidate as translator, Hugh Ross, had also been a royalist, as was John Boncle, the friend who had allegedly introduced Wall to Hugh. Hugh Ross, he speculates, could not have been "visibly an ideological royalist or an activist in the royalist cause." He does not elaborate on the grounds for making such a claim, except to speculate that "Perhaps [Hugh] told the authorities that he was motivated by personal loyalty more than political principle" 35 - this, regarding a person who had not only been in royal service in Oxford but who also made it a point to follow the Duke of York to the Netherlands, and continued in his service for several months. Nor does Malcolm consider it possible that Thomas Ross, too, could have been a circumspect royalist in the late 1640 s. As for Boncle, Malcolm goes a long way toward making him a "supporter" of the Parliamentarian regime, on account of his appointment to several educational positions during the 1650 os. ${ }^{36}$ However, there exists no evidence that Boncle was

31. HP 15/6/22B; 15/6/24A; 15/6/27A.

32. Malcolm, "English Translation of the Koran," 283.

33. A Transcript of the Registers of the Worshipful Company of Stationers, from 1640-1708 A.D., ed. George E. B. Eyre, 3 vols. (London, 1913-14), 1:317.

34. Having found no translations bearing Thomas Ross's name, Malcolm availed himself of Hartlib's statement as evidence for disqualifying Ross as the translator of the Koran. However, it is worth pointing out that no translations from the French can be attributed to Hugh Ross either.

35. Malcolm, "English Translation of the Koran," 279.

36. Ibid., 276. 
anything else but a royalist, who owed his advancement to the support of John Selden's circle as well as that of the Hartlib circle, at whose behest Boncle was appointed, in succession, master of the Charterhouse School, bedell of divinity at Oxford, and fellow of Eton College. A review of Boncle's career illustrates the manner in which erudite royalists could befriend religious and political radicals, and even secure learned positions during the Protectorate.

John Boncle was born around 1611 and appears to have been educated at the Charterhouse School. We find him employed between 1638 and 1641, together with his younger brother, George, in the service of Prince Charles and his siblings. They are listed under the heading "pastry," which helps explain a remark made by Brian Duppa in 1651, upon receiving a gift of pie from Justinian Isham: “your pastry man, though he hath not so many languages as Mr Boncle, hath so good a hand." George joined the king's army following the outbreak of the Civil War, and in 1644 his services were rewarded by a knighthood. He was taken prisoner at the battle of Naseby and died in captivity two months later. Another brother, Sebastian, also distinguished himself in the king's army, and probably left England at the end of the first Civil War.37 John Boncle's own whereabouts during the early 1640 s are not known. When petitioning Charles II in 1660, in an effort to retain his Eton fellowship, Boncle reminded the monarch how he "with divers others of his fellowe servants was sent backe from Newmarket to attend $y^{\text {e }}$ Royall Children then at London." 38 The summons probably occurred in late June 1647 , following the ten-day stay of Charles I at Newmarket Palace-his only visit there since early 1642 . Boncle remained in service until Parliament dissolved the household of the royal children in November 1648.

Boncle's scholarly attainments slowly percolated into learned circles. He befriended John Dury—-who had been appointed guardian of the royal children in March 1647-and Dury probably introduced him to Samuel Hartlib. By spring 1649 we find Boncle requesting Dury to procure for him various Socinian works from the Continent, as well as advising Dury-who had recently been dismissed from his position-on how to obtain a fellowship at Eton College. Abraham Wheelock, who had probably tutored Boncle at some stage, may have also helped advertise the latter's skills in Oriental languages. As early as November 1647 , he numbered Boncle among such "learned \& intimate friends," capable of furnishing Hartlib with an assessment of Wheelock's Koran project. 39 By 1650, if not earlier, Boncle appears to have established contact with both John Selden and Gerard Langbaine at Oxford. On October 29 Langbaine wrote Selden, expressing concern over the imminent ejection of "some persons of eminent parts from their stations in the University." In particular, he dreaded "irreparable" damage to the university if Edward Pococke, Laudian Professor of Arabic, were to be ejected.

37. William H. Brown, Charterhouse Past and Present (Godalming, U.K., 1879), 145-46; Margaret Toynbee, The Papers of Captain Henry Stevens Waggon-Master-General to King Charles I (Oxford, 1961), 59-62; The Correspondence of Bishop Brian Duppa and Sir Justinian Isham, 1650-1660, ed. Gyles Isham, Northamptonshire Record Society 17 (Northamptonshire, U.K., 1955), 29.

38. TNA, SP 29/9/126, fol. 159. I rely on Malcolm's transcription ("English Translation of the Koran," 277).

39. HP 41/1/31A;33/4/3B. For Wheelock's project, see below. 
Contemplating a possible remedy to such a loss, Langbaine added: "for the Arabick lecture (if there be no hopes of Mr Pococks continuance, as I feare there is not) then the bearer (for ought I know) in regard as he is no stranger to the tongue already, and being yonge \& studious may by that employment in a short time become completely able to discharge that function) I conceive may be as fitt to succeed as another; though being sufficiently knowne unto your self already he needs no recommendation from me, yet at his request I have presumed thus farre to interpose. When you have occasion to make use of him I know he will be very ready to serve you in any kind so shall." 40 The "bearer" of the letter, I believe, was Boncle. Certainly, by March 1651 Boncle's familiarity with Selden enabled him to furnish Hartlib with information regarding Selden's scholarly habits. A year later (March 16, 1651/2), Langbaine explicitly recommended Boncle for a position at Oxford. If it proved impossible to persuade Patrick Young to accept the Bodleian librarianship, he wrote Selden, "by all that I have heard $\mathrm{Mr}$ $\mathrm{B}$ [unk]ly may doe as reall service in the place as Mr Hartlib. And if an English man be as fit, what reason there may be, to preferre a stranger." 41

Two months earlier, January 1652, Boncle had been appointed headmaster of Charterhouse School. In Malcolm's view, this and two subsequent appointments suggest that Boncle "was regarded with some favour by Cromwell and his circlewhich in turn suggests that he was understood to be a supporter of the regime." 42 I disagree. Boncle's advancement should be credited to the influence of learned friends who petitioned powerful grandees on his behalf. Thus, for example, Oliver Cromwell's letters of October and December 1652 to Oxford University, whose chancellor he was, urging the university confer a master's degree-and later the position of bedell of divinity-on Boncle, need not assume personal acquaintance; the protector often signed his name to documents prepared by others, quite a common practice at the time. In fact, Cromwell openly noted the intercession of intermediaries in one of his letters: "and truly his eminent learning and piety being such as I am informed, I cannot but judge that ... hee would be a very considerable ornament to Your University." We may infer the impersonal nature of such recommendations from another letter of recommendation of Cromwell to Oxford, this time requesting the University to confer a medical doctor's degree on John Widenbanke, the royalist son of Charles I's secretary of state. Cromwell stated even more explicitly how he acted at the behest of others, "being desired by a worthy friend to recommend him unto you." 43 Small wonder that Langbaine informed Selden with some satisfaction - in a December 1652 letter carried by Boncle-that the university "have unanimously made choyce" of Boncle as bedell. 44

Having established that Hugh Ross and Boncle probably met while serving the royal children, and having identified the former as the "friend" of Wall who had translated the Koran, Malcolm suggests that Hugh Ross left the manuscript of the

40. Bodleian Library (hereafter cited as Bodl.), MS Selden supra 109, fol. 323.

41. HP 28/2/12A; Bodl. MS Selden supra 109, fol. 465.

42. Malcolm, "English Translation of the Koran," 276.

43. The Correspondence of John Owen (1616-1683), ed. Peter Toon (Cambridge, 1970), 54-55

(emphasis added), 64 .

44. Bodl., MS Rawlinson D 390, fol. 22. 
Koran translation in Thomas Ross's hands before leaving for the Netherlands in early summer 1649, and that it was owing to his absence from England that Thomas Rossafter an unexplained delay of four or five months-delivered it to the printer a few weeks prior to its licensing and registration on December 29, 1648.45 Why, one may ask, didn't Hugh himself seek a publisher before leaving England? Alternatively, why would he choose to leave the manuscript in the hands of the young Thomas Ross rather than with the better known, and better connected, Alexander Ross-whom Hugh described in his will as one of the three "nearest in blood" to him? Such questions are pertinent given the concerted effort Malcolm makes to establish uni-directional relations between members of the Ross clan.

Malcolm produces no evidence for a connection between Hugh and Thomas, other than to state that Hugh was Thomas's uncle. Noteworthy, however, is that Hugh was a distant uncle, in both senses of the word. Hugh was the eldest son of Walter Ross of Balmachy and his wife Margaret Munro, whereas John Ross, Thomas's father, was the firstborn son of Walter's union with his second wife, Jean Douglas (see figure 1). Thus, not only had a considerable age gap separated Hugh from his half brother James, but the two were separated geographically as well. Hugh retained his Scottish roots, even while spending much of the period after 1625 on the Continent, working on behalf of British prisoners and their goods. For his part, James moved to England where he became page of the bedchamber to Charles I. A certain familial alienation can also be detected. James Ross's will made no mention of his half brothers; indeed, it left out even James's son from a previous marriage-Robert Ross of the Charterhouse-although it did provide for Robert's daughter.

Establishing the relations between members of the Ross clan is necessary for there exists an asymmetry in Malcolm's argument. He considers the mention of Alexander Ross in Hugh Ross's will significant, for it furnishes evidence of contact between the two. In contrast, the failure of Alexander Ross to mention Thomas in his own will (written in February 1654) suggests that the relations between the two "had not been particularly close or amicable." However, I find it significant that Hugh Ross did not mention Thomas Ross in his will. In fact, the date of Hugh's will-June 19, 1649, several weeks after Thomas had allegedly risked his freedom by appearing before the Council of State to take the blame for the translation-should have made his omission from Hugh's will more significant than Alexander's failure to mention him five years later. Surely, if Thomas had been so selfless, even the impoverished Hugh would have made it a point to bestow on Thomas some small token of gratitude in his will. Consequently, I find it difficult to accept Malcolm's deducing that, since Alexander left no legacy to Thomas, it "is easier to imagine" that the former "wrote his 'Needfull Caveat' as a personal favour to Hugh Ross than that he did so at Thomas's request." 46

In the absence of any tangible evidence connecting Hugh Ross to the English translation of the Koran-or, for that matter, to Thomas Ross-great caution must be exercised before rejecting the solid historical evidence that vests responsibility for the

45. Malcolm, "English Translation of the Koran," 279.

46. Ibid., 280 . 


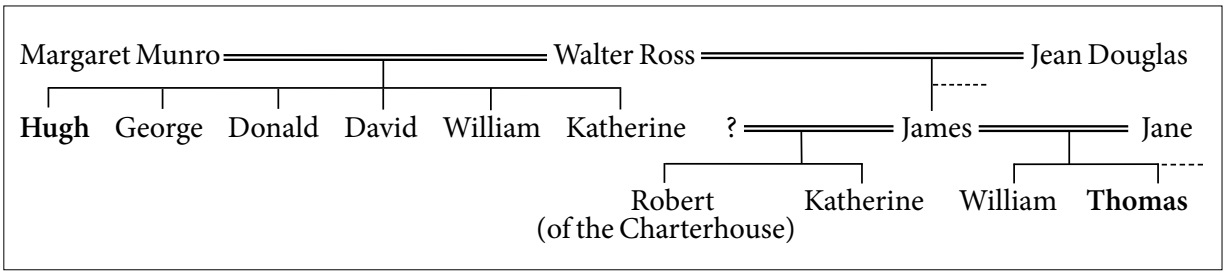

FIGURE 1. Family tree showing the relationship of Hugh and Thomas Ross (in bold).

Alcoran squarely in the hands of Thomas Ross. To reiterate: Thomas Ross was the person whom the printer had identified as responsible for the translation, and whom the Council of State hauled in for investigation-not a trivial matter in the immediate aftermath of the regicide. Evidence exists for Thomas's knowledge of French, 47 and it is not necessary to single out Hugh Ross's connection to Alexander Ross in order to explain the latter's contribution of the "needful Caveat" to the volume. The request may well have originated from the bookseller John Stephenson, who stood to lose a small fortune if the book were to be suppressed. Alternatively, the official censor, John Downame, could have enlisted Alexander Ross, having previously warmly endorsed several of his books.

\section{粉}

We are now in a better position to evaluate the broader reaction to the publication of the Alcoran. It has often been assumed that a few published denunciations of the translation are indicative of a general hostility. According to Alastair Hamilton, for example, the trouble encountered by the English translator of Du Ryer's version "proved that it was still very far from safe to translate a work which caused such fear and aroused such prejudice." 48 Malcolm concurs, conjecturing that "it seems reasonable to suspect that the popular outcry against the printing of the Koran might have had some influence" on the abortive effort to publish the translation of Baudier's History of the Religion of the Turkes. Malcolm also believes that the translation of the Alcoran was not suppressed owing to "tolerationist sympathies in the Council of State, where Independents of various kinds formed the dominant element" - further regarding the few instances of critical reception to be discussed below as reflecting a genuine concern "that England was moving down a slippery path towards the toleration of every sort of heresy, blasphemy, and infidelity." 49

Had there really been a widespread popular opposition to the translation per se? Without ignoring the pervasive anti-Muslim sentiment of the time, we should view the immediate reaction within a more limited polemical context. It is my contention that

47. In the aftermath of the March 1655 failed Royalist uprising, a witness described Thomas Ross as "a great schollar, for that he heard him speak Latin, Greek, and other languages, besides Dutch and French"; A Collection of the State Papers of John Thurloe, ed. Thomas Birch, 7 vols. (London, 1742), 3:348. 48. Hamilton and Richard, André Du Ryer and Oriental Studies, 93.

49. Malcolm, "English Translation of the Koran," 285, 294. 
the several hostile remarks that appeared in print following the publication of the Alcoran should be interpreted as coming out of the partisan atmosphere that had engendered Anthony Weldon's denunciation-and the initial attempt by Parliament to halt publication-not as reflecting serious alarm at the foreboding consequences for Christian orthodoxy. The chatter in the immediate aftermath of the publication of the Alcoran came invariably from opponents of the regime. Within four months an anonymous Presbyterian pamphleteer found it opportune to draw attention to the translation as part of his attack on a petition submitted by Colonel Pride to the House of Commons on August 16, 1649-in the name of the Council of Officers-which demanded religious toleration through the repeal of all ordinances "whereby many conscientious people are molested, and the propagation of the gospel much hindered." The pamphlet, purporting to be the work of the venerable Richard Holdsworth, who had died on August 22, denounced the "diabolical" ploy of Pride and his cronies to revoke the very legislation that hitherto prevented "Sectaries \& Hereticks" from "dispersing their damnable Tenents." Nor did the author find solace in the exclusion of Catholics from the proposed measure, convinced as he was that the alleged toleration would surely "bring in as many Heresies as houses, and as many Opinions as there be people." As proof, the author invoked the publication in English of "that Academy of Heresies, the Turkish Alcoran," a book that over the previous century "was treason in any one to transport hither, much less Translate." The pamphleteer proceeded to cite "a learned holy man" who had observed that in order to make the translation "more vendible and acceptable, all the gross absurdities [were] left out"! 50

The royalist author of this pamphlet was evidently less concerned about the presumed mischief that the Alcoran of Mohamet augured for Christian religion than the prospect of exploiting such publication as a weapon in his impassioned denunciation of the petition by several army officers to repeal the entire penal code governing religion. Such pragmatic considerations informed polemicists on the other side of the political divide as well. Case in point: the second part of Clement Walker's Anarchia Anglicana: Or, the history of independency (1649), which proved a far more vehement (and influential) contribution to the charged religious atmosphere of the period. Until his ejection during Pride's purge in December 1648 for his vociferous opposition to the king's trial and to the Independents, Walker sat in Parliament. He vented his animus against the regime and the Independents in his History - a publication that quickly landed him in jail, where he would die in 1651. In that work, among other things, he narrated the appearance "out of the East a New Light in our Horizon, the Alchoran of Mahomet (Predecessor to Cromwell) and of Sergius (forerunner of Hugh Peters). Now the Jewes (professed Enemies to Christ (which Mahomet is not) are accepted off) it is believed that their Thalmude and Caball will shortly be made English too, that this Island may be rendered a compleat Pantheon, a Temple and Oracle for all Gods and all

50. Blair Worden, The Rump Parliament (Cambridge, 1974), 208; Richard Holdsworth, pseud., An Answer without a Question: Or, the Late Schismatical Petition for a Diabolicall Toleration of Severall Religions Expounded (London, 1649), 5-6. 
Religions; our light headed innovating People being like Reeds as apt to be shaken by, and bend unto every wind, every breath of pretended inspiration, as the ancient Arabians were." Several pages later he added: "I wish this Gentleman would read the Alchoran (or new Independent Bible of the new Translation) and from thence gather precepts of more Humanity, Justice, Honesty and Courage, since he hath Read the Old and New Testament of Moses and Christ to so little purpose."51

Contemporary royalist newspapers, in particular, found in the publication of the Alcoran useful fodder for their antigovernment propaganda. Consider the Man in the Moon, a newsbook that John Crouch launched in April 1649. The weekly did not intend to furnish news per se. Rather, Crouch sought to ridicule the regime and its grandees by any means possible, irrespective of the accuracy of his information. Unsurprisingly, Crouch used the publication of the Alcoran as ammunition when denouncing in the 5 th issue (May 21-30) both the Council of State and the more elite "Juncto," for attempting to suppress his own newsletter while permitting the publication of the Koran:

\section{But let them rage, and doe their worst, wee'l make the Rebells worke, \\ And make them in the Presse accurst, that Alkaron print for Turke}

He concluded the issue by "advertising" the publication of "a new Book printed by Authority of Parl. call'd the Turkish Alcharon; worthy your most serious devotions."

Like other royalists, Crouch regularly denounced the "tyranny" of the government-a tyranny that appeared to be codified by the draconian Treason Acts of May 14 and July 17, 1649. These laws, among other things, made it a capital offense to "publish by Writing, Printing, or openly Declaring, that the government is Tyrannical, Usurped or Unlawful." Such tyranny had often been associated in the popular mind with Turkish rule; hence Crouch continued to invoke the theme in subsequent issues. The 9 th issue (June 5-13) concluded with an ominous prediction: "Before these Traytors will give o're their wORKE, / They'l arme the Devil, and call in the Turke." Two issues later, Crouch denounced the regime for purposely ordering the publication of "Papists and Jesuites Works" which, he claimed, were sold "Cum privilegio" at St. Paul's Churchyard. "I forgot the Turkish Alkaron," Crouch added, "but these may suffice to unblind the Nation, and let them see into what Trusty hands, and religious Saints they have committed the keeping of their Religion, King, Priviledge of Parliament, Liberties and Lawes." 52

51. Theodorus Verax [Clement Walker], Anarchia Anglicana: Or, the history of independency. the second part (London, 1649), 166, 172.

52. [J. Crouch], The Man in the Moon, Discovering a World of Knavery under the Sunne, no. 7 (May 21-30, 1649), 59, 66, 82, 90-91 (mis-numbered for 100-101). For a discussion of Crouch and his periodical publications, see Jason McElligott, "John Crouch: a Royalist Journalist in Cromwellian England," Media History 10 (2004): 139-55. 
There was nothing particularly original in either the content or the language of such journalistic attacks. Marchmont Needham's Mercurius Pragmaticus for April 4-11, 1648 , for example, opened with the following verse

\author{
Come Mahomet, thy Turn is next; \\ Now Gospel's out of date, \\ The Alcoran may prove good Text \\ In our new Turkish state
}

But the publication of the English translation of the Koran gave the pervasive prejudice
greater strength. The anonymous author of The Famous Tragedie of King Charles I, for
example, published some three weeks after the Alcoran, managed to insert into his play
an opening dialogue between Cromwell and his "better Genius"-Hugh Peter. The
author depicted Cromwell as relying on the latter's counsel more than "on the Sybils
words or Delphian Oracle": "Thou art that Load-stone, which shall draw my sense to
any part of policy i'the Machiavilian world, we two (like Mahomet and his pliant
Monke) will frame an English Alchoran, which shall be written with the self-same pen-
sil great Draco grav'd his Lawes." 53 John Birkenhead's satirical assault on the Assembly
of Divines-defunct since 1648-was wittier, including a spoof that took its cue from
the publication of the translation of the Alcoran: "The great Turk was sending his
ambassador to congratulate the assembly's proceedings against the Christians; he
ordered them thanks for licensing his alcoran to be printed in English; but hearing
Ottoman Cromwell had talked of marching to the walls of Constantinople, that
ambassy was stopped." 54

Other instances of royalist manipulation of the English Alcoran for political ends-rather than reflecting genuine concern for religion-include an August 1649 manifesto by Sir Lewis Dyve and Sir Marmaduke Langdale, aimed at explaining their support for the Earl of Derby's attempt to keep the Isle of Man loyal to Charles II. The two denounced not only the regicide and the arrogation of power by Parliament but also the abolition of all the ancient rites of the Church of England and their substitution by "factions, seditions, schismes, heresies and unparalell'd blasphemies." Notable among these was the granting of "a generall toleration of all Religions, and (as we heare) have not only permitted but ordered the Turkish Alchoran to be printed in English." 55 For his part, Thomas Killigrew, Charles II's special envoy to Italy, sought on February 14, 1650, to enlist the support of the Grand Duchy of Florence for the royal

53. The Famous Tragedie of Charles I (London, 1649), 3-4. For a discussion of the play, see Matthew Birchwood, Staging Islam in England: Drama and Culture, 1640-1685 (Woodbridge, U.K., 2007), 52-68.

54. Sir John Birkenhead, The Assembly-Man Written in the Year 1647 (1663), in The Harleian Miscellany, 10 vols. (London, 1808-13), 6:60. This part of the satire was obviously added after May 1649. For a brief discussion of the work, see P. W. Thomas, Sir John Berkenhead 1617-1679: A Royalist Career in Politics and Polemics (Oxford, 1969), 146-50.

55. A Declaration of the Noble Knights, Sir Marmaduke Langdale, and Sir Lewis Dives; in vindication of the Right Honourable, James Earle of Darby: and remonstrating their resolutions to keep the Isle of Man ... for His Majesties service (London, 1649), 3-4. 
cause by submitting a lengthy narrative of the political and religious evils introduced by the new regime. Once again, Ross's translation came in handy: "The danger to the Christian religion is shown by the sects which have sprung up in the new empire, to the number of fifty all of which may be professed to-day in England with the utmost liberty. So also by the burning of the sacred liturgy by the hangman and at the same time the publication of the Alcoran, translated from the Turkish, so that the people may be imbued with Turkish manners, which have much in common with the action of the rebels." 56

As these examples make clear, the seeming condemnation of the publication of the English Alcoran was motivated not by any perceived threat to religion but by the polemical role it could serve-hence the preponderance of royalists among those who availed themselves of the news of the translation. Indeed, that same polemical agenda was carried into the early eighteenth century by the early historians of the "Puritan Revolution." According to Daniel Neal, Bishop White Kennett thundered against the licensing of The Alcoran of Mahomet by a Presbyterian minister as indicative of the proliferation of heresies unleashed by the revolution. Neal responded to the charge somewhat sarcastically: "Sad times! Was his lordship, then, afraid that the Alcoran should prevail against the Bible? or that the doctrines of Christ could not support themselves against the extravagant follies of an impostor? But the book did no harm, though the Commons immediately published an order for suppressing it; and since the restitution of monarchy and Episcopacy, we have lived to see the life of Mohammed and the Koran published without mischief or offence."57

Polemical purposes aside, concern over the availability of the Koran in the vernacular certainly existed, and it could transcend political or denominational boundaries. With greater sincerity than John Crouch, the prophetess Eleanor Davies expressed dismay in 1650 at the publication of the Alcoran "Cum Privilegio," as well as its being openly sold in the bookshops at St. Paul's Churchyard. ${ }^{8}$ In the very letter of May 2, 1649, in which he announced the publication of Ross's translation, John Dury urged his correspondent to procure from Manasseh Ben Israel and other Dutch rabbis as much information as possible regarding Jewish refutations of Islam and the lives of the prophet-material that might "inable some of us to serve the publicke in discovering the falshood of the Mahumetan Religion, whereof the Law is now published, and made common." 59 Six years later we find the aging minister Edward Terry-whose religious orthodoxy allowed him to retain his vicarage throughout the Civil War and Interregnum-bewailing the spread of atheism as a result of the neglect into which

56. Calendar of State Papers and Manuscripts Relating to English Affairs, Existing in the Archives and Collections of Venice, vol. 28, 1647-1652, ed. Allen B. Hinds (London, 1927), 138.

57. Daniel Neal, The History of the Puritans, 2 vols. (New York, 1844), 2:113. Neal's outburst is probably the source of Gardiner's quip that "the book appeared, without causing a change in the religious views of a single Englishman." Samuel R. Gardiner, History of the Commonwealth and Protectorate, 1649-1656, 4 vols. (London, 1903), 1:56.

58. Eleanor Davies, Elijah the Tishbite's Supplication (1650) and Restitution of Prophecy (1651), in Prophetic Writings of Lady Eleanor Davies, ed. Esther S. Cope (Oxford, 1995), 326, 354.

59. $\mathrm{HP} 4 / 1 / 26 \mathrm{~B}-27 \mathrm{~A}$. 
scripture had fallen: "when people instead of the writings of Moses, and the Prophets, and Evangelists, and other parts of that most sacred Book, which was wont to lye in their windows, as their best ornament \& to sit in their uppermost rooms as their best Ghest in their houses, there are many Romances, and other vain and frivolous stories, which take up their places, much viciating and corrupting the minds of many Readers; who rather than they should want Books, that might afford matter to please and feed their wanton humours, have the Turkish Alcoran taught to speak English." 60

More than constituting a sustained attack on the English Koran, then, these and related comments were variants of pervasive anti-Islamic rhetoric during the early modern period, a version of which had been incorporated into Alexander Ross's "needfull Caveat" as well. What differentiated the English translation from similar ventures, as I suggested above, was its unabashed commercialism. Whereas Du Ryer had aspired to literary fame in addition to commercial success, Thomas Ross and John Stephenson appear to have set their eyes squarely on profit. Such motivation was largely absent from contemporaneous projected scholarly editions or translations of the Koran, and a brief analysis of these learned projects should further elucidate the intellectual milieu out of which the English translation emerged.

Joseph Justus Scaliger was instrumental in elevating oriental learning to a position of prominence at the turn of the seventeenth century. Not only did his own forays into Arabic confer dignity on the discipline, but he also encouraged several gifted young men-Thomas Erpenius and Joannes De Laet, in particular-to pursue such study. Significantly, Scaliger was convinced that a narrow focus on Arabic versions of scripture was inadequate for attaining mastery of the language and culture of Islam. When Isaac Casaubon informed him in 1603 that he had embarked on a study of Matthew's Gospel in Arabic, Scaliger gently strove to dissuade his friend from following such a method of study: "you can no more learn [Arabic] perfectly without the Koran than you can learn Hebrew without the Bible. For the Arabs can say nothing without alluding to some passage or saying from the Koran." 61 Scaliger further advocated a disinterested study of Arabic language, literature, and history, advising others not to undertake such study simply in order to confute Islam. ${ }^{62}$

In so doing Scaliger was ahead of his time, and Thomas Erpenius, the first Leiden professor of Arabic, largely embraced this broad view. He developed a deep appreciation of the Arabic language and shared Scaliger's opinion concerning the necessity of basing the study of Arabic on the Koran. Toward that end, Erpenius published in 1617 an edition of the twelfth Sura (Historia Josephi Patriarchae, ex Alcorano, arabicè. Cum triplici versione Latina \& scholiis), further announcing his intention to translate the entire Koran into Latin, "honestly explained and thoroughly refuted." Erpenius's untimely death in 1624 put an end to this project. Erpenius's successor, Jacob Golius, also planned to produce a translation of the Koran, complete with a "refutation of

6o. Edward Terry, A Voyage to East-India (London, 1655), 463-64.

61. Alastair Hamilton, "Isaac Casaubon the Arabist: 'Video Longum Esse Iter,'” Journal of the Warburg and Courtauld Institutes 72 (2009): 143-68.

62. Alastair Hamilton, William Bedwell the Arabist, 1563-1632 (Leiden, 1985), 84. 
its 'errors,'” but this translation was never published either. ${ }^{63}$ According to Daniel Heinsius-in response to an inquiry by John Selden in 1633 on the feasibility of publishing the Koran in Arabic in the Netherlands-both Erpenius and Golius had proposed such an edition, but their efforts had been "obstructed by some of those who deal with religious affairs. For they think that a book full of false doctrine and dangerous superstition (to use their own words) should neither be published nor translated into Latin by Christians." Heinsius, of course, saw matters differently. The Arabic text could harm neither the majority of people, who were ignorant of the language, nor the Arabists, "who can readily perceive these fatuities by their own abilities." For the same reasons, he concluded, a Latin translation of the Koran could endanger hardly "anybody at all." 64

The nature and extent of the opposition is difficult to gauge. Conservative theologians were bound to detect heresy in any scholarly project, and such accusations were particularly rife in the years following the Synod of Dort. Still, not all Dutch Calvinists were opposed to such a publication. Gisbertus Voetius, for one, who had studied Arabic with Erpenius, lamented in the 1640 s the absence of a complete edition of the Koran in Arabic. ${ }^{65}$ It is also difficult to determine whether Selden's inquiry about publishing the Koran in the Netherlands meant he was seriously contemplating such an enterprise himself, though John Gregory, a promising Oxford orientalist, appears to have believed he was. ${ }^{66}$ Gregory, in fact, strongly advocated publishing an edition and a translation of the Koran, for the benefit of both scholars and future opponents of Islam:

I was asked once by an able and understanding man, whether the Alcoran as it is of it self had so much in it as to work any thing upon a Rational belief. I said, Yes. Thus much only I required, That the Believer should be brought up first under the engagement of that Book. That which is everywhere called religion hath more of Interest and the strong impressions of Education than perhaps we consider of. Otherwise for the Book it self it is taken for the greater part out of our Scripture, and would not hear altogether so ill, if it were looked upon in its own Text, or through a good

63. J. Brugman and F. Schröder, Arabic Studies in the Netherlands (Leiden, 1979), 13.

64. Gerald J. Toomer, "John Selden, the Levant, and the Netherlands in the History of Scholarship," in The Republic of Letters and the Levant, ed. Alastair Hamilton, Maurits H. van den Boogert, and Bart Westerweel (Leiden, 2005), 53-76 at 59. Such opposition was expressed, for example, by Adam Boreel in 1626: "Editionem Alcorani quod attinet, si meum esset sententiam dicere, subsisterem. Est vere illud somniorum farrago, saepe etiam cum injuria Historiae Sacrae. Habet Hollandia multos profanos, multos somniorum admiratores, qui facile ex lectione ineptissimi profanissimique scripti, argumenta sibi somniabunt contemnendi illos libros, quos ipsi nunquam attente legerunt, qui continent aeternam invictamque de Filio \& Sp. S. Doctrinam"; quoted in Peter T. van Rooden, Theology, Biblical Scholarship, and Rabbinical Studies in the Seventeenth Century (Leiden, 1989), $61 n 38$.

65. Karel Steenbrink, Dutch Colonialism and Indonesian Islam: Contacts and Conflicts 1596-1950 (Amsterdam, 1993), 53. Voetius promoted in 1646 the publication of Juan Andrés's Confusio sectae Mahometanae, to which he contributed a preface refuting Islam.

66. Bodl. MS Selden supra 108, fol. 52, cited in Gerald J. Toomer, John Selden: A Life in Scholarship (Oxford, 2009), 619. 
Translation. But (not as to gain any thing by this) the Alcoran is scarcely translated yet. The best disguise of it is that in Arragonois by Joannes Andreas the moor, but the entire Copy of it is not easily met with. ${ }^{67}$

Gregory's sentiments reflected the prevailing opinion among learned scholars in pre-Civil War Oxbridge. Consider the estimation of John Bainbridge, Savilian Professor of Astronomy at Oxford, regarding the indispensability of the Koran for learning Arabic. In the 1620s, when preparing an edition of Ptolemy's Almagest, Bainbridge sought to include material from Arabic copies of the work as well as to incorporate astronomical observations carried out by Arabs. When he could not, owing to his ignorance of Arabic, Bainbridge embarked on a serious study of the language. Writing to Archbishop James Ussher in 1626, he recounted his progress. Having come across an Arabic astronomical work, Bainbridge claimed now to be able to comprehend the tables:

but the canons annexed are more difficult, and yet do so much the more incite me to find out that particular meaning, which is not possible without knowledge in the Arabic; whereof I have made entrance into the rudiments thereof, and hope, labore et constantia, at length to be able to translate any Arabic book of mathematics. It is a difficult thing which I undertake, but the great hopes I have in that happy Arabia to find most precious stones for the adorning and enriching my $\Sigma v v \tau \alpha \xi_{\llcorner\varsigma}$

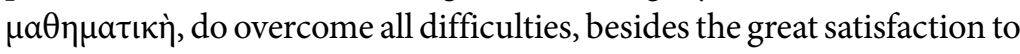
see with my own eyes ... and not to be led hoodwinked by others, who though they may be expert in that tongue, yet without special skill in these particular sciences, cannot truly translate the Arabic.

Toward that end Bainbridge requested Ussher to procure for him a "good Arabick Copy of the Alkoran, the only Book whereby that Language is attained." 68

Indeed, judging by the number of English Arabists who announced editions, translations, and refutations of the Koran during the first half of the seventeenth century, conditions in England seemed propitious for such undertakings. Abraham Wheelock, the Adams Professor of Arabic at Cambridge, avidly embarked on not only an Arabic edition of the Koran-with an accompanying Latin-Greek translation-but also a thorough refutation of it in Arabic. The project appears to have enjoyed wide support at Cambridge. According to Thomas Smith, the regent masters had approved publication of Wheelock's edition at the university's expense, and Smith hoped to persuade the regents also to approve the forging of a new Arabic font, again at the university's expense. However, probably owing to the machinations of Christian Ravius, Wheelock failed to win Samuel Hartlib's support and consequently abandoned both

67. John Gregory, Notes and Observations upon some Passages of Scripture, in The Works of the Reverend and Learned Mr. John Gregorie, 4th ed. (London, 1684), sig. a2v (second pagination).

68. James Ussher, The Whole Works, ed. C. R. Elrington, 17 vols. (Dublin, 1847-64), 15:351-52. 
projects. As he intimated to Archbishop Ussher, "Mr. Hartlib returned my Papers, and told me they were not, or else my Intention was not, approved. I purposedly was desirous to be ignorant who should give this severe Censure." 69

Ravius's obstructionist tactics derived, in no small part, from his own ambition to produce an edition of the Koran. As early as 1643 he expressed his opinion that the (legendary) burning of Paganini's Arabic edition of the Koran (ca. 1538) had been motivated by no other reason than "it was printed with very bad types," and the Turks thought that the bad printing of the Koran "was done to mock their religion." If, on the other hand, he himself had published the Koran using his "Chalcographia," the Muslims "would never have rejected it or shown any scruples; they could have turned it into a huge trading commodity for the East Indies and Turkey, and the whole of Africa and Asia." Ravius continued: "The most learned men have always been amazed at the judgment of those who thought that it would imperil the Christian faith if the Koran were published. For these Timons apparently cannot see how much difference there is between the two religions, how distant from each other are God and Belial, Christ and the prince of darkness." 70 Ravius obviously toyed with the idea while in London in 1648. That year he informed Hartlib that a grocer, Jackson by name-presumably one of his students-had acquired "an excellent dexterity" in Arabic. The grocer's brother was the bookseller Thomas Jackson, the publisher of Ravius's Generall Grammer for the Ebrew, Samaritan, Calde, Syriac, Arabic and Ethiopic Tongue (1649?). The two contemplated a plan "to cause all the Alcoran to bee graven and so printed which will Exceed all that ever hath beene done and may be insinuated by Merchants to the Turks with the Refutation which will seeme to bee fairly written. But it will cost some thousands of lib."71

Other English Arabists were hard at work on similar projects. John Boncle is a case in point. In early summer 1648, Hartlib was informed that Boncle was preparing "an exact Concordance upon the Alcoran," which he intended to publish with the original text and a translation, along with extensive notes illustrative of "how ignorantly and falsly Mahomet hath taken his stories and doctrines out of the Bibel or other Legends, which will serve instead of larger confutations." Boncle's zeal to refute Islam was further illustrated in his plan to translate Johannes Maurus's confutation of the Koran: he told Hartlib he intended to procure a Spanish edition of the work as he found the Latin version defective. ${ }^{72}$ In the following decade, we find the English orientalist Thomas Greaves, too, laboring on a translation and commentary on the Koran, and even more intently, on a long refutation of Islam-a religion "which is one of the great

69. HP 15/6/27A; Ussher, Works, 16:176. Ravius initially sought to thwart Wheelock's progress in a more subtle way, suggesting the latter should publish first Bedwell's Arabic lexicon. Wheelock and his Cambridge friends refused, all agreeing "he should rather first consummate the Alcoran"; HP 15/6/27A.

70. Christian Ravius, Panegyrica Prima Orientalibus Linguis (Utrecht, 1643), 18.

71. HP 31/22/39A-B; Plomer, A Dictionary of the Booksellers, 106. Ravius published in 1646, probably at his own expense, Prima tredecim partium Alcorani Arabico-Latini-a transliterated edition of the first two suras of the Koran, with a separate literal Latin translation. The title, as well as many other declarations, make clear his intention to publish the whole Koran, although he never proceeded.

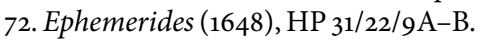


depths of Satan." His refutation, Greaves informed Richard Baxter, was based on Arabic sources, and he sent Baxter a specimen of it to demonstrate how the very testimony of Christianity's "chief adversaries" can serve to better induce "belief of the Christian religion."73 For his part, John Worthington, master of Jesus College, Cambridge, pressed for an edition of the Koran for years. As late as 1659 he hoped that Hartlib would use his influence to dissuade Johann Heinrich Hottinger from turning to controversial theology - in order to write a history of the Reformation-and encourage him instead to "follow mainly the advancement of Oriental studies" and, in particular, fulfill his promise to publish an edition of the Koran. Such an edition was a desideratum, Worthington insisted on several occasions, for "ifChristians would more knowingly and pertinently deal with Jews and Mahometans, they should be acquainted with the Mishnaioth and the Alcoran."74

Hartlib approved of the idea. Many were "strongly prepossessed agst the Alcoran," Hartlib noted, but Levinus Warner's edifying Compendium historicum eorum quae Muhammedani de Christo et praecipuis aliquot religionis Christianae capitibus tradiderunt (1643) - where "all the passages concerning Christ are collected out of the Alcoran"- "would make the original acceptable." 75 Hottinger, however, ultimately disappointed too. He had advertised his intention to publish a new edition and translation of the Koran ever since 1641 . But his ambition was quickly dampened by Louis Cappel, who pointed out to the young Zurich professor that "a new translation should at least match Erpenius's exemplary edition of the Sürat Yūsuf-which meant an edition of the Arabic text, a collation of variant readings and, of course, a translation that surpassed the existing ones." Furthermore, Cappel continued, "the uses of a new translation of the Koran would never justify these labours and difficulties," as the existing translations sufficed for undertaking "the one thing that was really necessary for a Christian, namely to refute 'libri illius vanitas, falsitas, absurditas atque impietas.' "76

In later years, Hottinger contemplated publishing the translation of the Koran as part of a much more ambitious universal history of Islam, another project that never bore fruit. Hottinger thus joins the ranks of countless seventeenth-century Arabists who failed to deliver on their promise to produce an edition and/or a translation of the Koran. The reasons for such a collective failure were many and diverse-including early death, perfectionism, procrastination, a lack of proper types, and the reluctance of publishers to undertake such projects. However, "popular prejudice which made the publication of the Quran so perilous," 77 hardly figured among such reasons, as a more comprehensive study of the topic would demonstrate.

73. John Greaves, Miscellaneous Works, 2 vols. (London, 1737), 1:lxiii-lxvi; British Library MS 21901; G. J. Toomer, Eastern Wisedome and Learning: The Study of Arabic in SeventeenthCentury England (Oxford, 1996), 208-9.

74. The Diary and Correspondence of Dr. John Worthington, ed. James Crossley, 2 vols. in 3 (Manchester, 1847-1886), 1:181, 242-43, 345, 320; 2:23-24.

75. Worthington, Diary and Correspondence, 1:180; The Correspondence of Robert Boyle, ed. Michael Hunter, Antonio Clericuzio, and Lawrence M. Principe, 6 vols. (London, 2001), 1:391.

76. Jan Loop, “Johann Heinrich Hottinger (1620-1667) and the 'Historia Orientalis," Church History and Reformed Culture 88 (2002): 169-203 at 177-78.

77. Alastair Hamilton, “The Study of Islam in Early Modern Europe," Archiv für Religionsgeschichte 3 (2001): 169-82 at 174 . 
I wish to thank Noel Malcolm for a stimulating exchange and for furnishing me with the final draft of his article before publication. I would also like to thank Sara Austin, Susan Green, Kristine Haugen, Carol Magun, and Gerald Toomer for very helpful comments.

MORDECHAI FEINGOLD is a professor of history at the California Institute of Technology. His publications include The Newtonian Moment: Isaac Newton and the Making of Modern Culture (2004) and (with Jed Buchwald), Isaac Newton and the Origin of Civilization (2012). He is currently working on the history of the Royal Society. 